\title{
СПЕЦИФИКА РОССИЙСКОЙ УРБАНИЗАЦИИ И ЕЕ ВЛИЯНИЕ НА ЭКОСИСТЕМУ ГОРОДА
}

\section{Майснер Татьяна Николаевна}

К. ф. н. ФГБОУ ВО "ЮРГПУ (НПИ) имени М.И. Платова"

\begin{abstract}
Аннотация: Статья посвящена анализу специфики российской урбанизации и ее влиянию на экологическое состояние российских городов. В российских процессах урбанизации выделяются два периода - советский и постсоветский, которые во многом определили сегодняшнее экологическое состояние многих российских городов.
\end{abstract}

Ключевые слова: урбанизация, советская урбанизация, постсоветская урбанизация, природопользование, деурбанизация, депрессивные города, мегаполизация.

\section{THE SPECIFIC NATURE OF THE RUSSIAN URBANIZATION AND ITS IMPACT ON THE CITY'S ECOSYSTEM}

\section{Tatyana Nikolaevna Meisner}

\begin{abstract}
The article is devoted to the analysis of the specific nature of the Russian urbanization and its impact on the environmental situation of the Russian cities. Two particular periods in the Russian urbanization processes - Soviet and postSoviet largely determined the current environmental situation of many Russian cities.

Key words: urbanization, Soviet urbanization, post-Soviet urbanization, nature management, deurbanization, depressed cities, megapolisation.

Исследуя специфику российской урбанизации, отечественные исследователи выделяют в ней периоды, связанные со сменой политической власти в XX в. - советский и постсоветский [1]. Урбанизация советского периода отражала характерную для российской цивилизационной специфики стремительность перехода из одной крайности в другую, исторически инициируемую политической властью и носящую искусственнопринудительный характер. Поскольку аграрная страна за короткое время должна была превратиться в страну индустриальную, процесс урбанизации не
\end{abstract}




\section{НАУКА, ОБЩЕСТВО, ТЕХНОЛОГИИ: ПРОБЛЕМЫ И ПЕРСПЕКТИВЫ ВЗАИМОДЕЙСТВИЯ В СОВРЕМЕННОМ МИРЕ}

мог носить эволюционного характера. Рост городов и увеличение численности их населения инициировался и направлялся государством и был обусловлен необходимостью изменения локации производительных сил рядом с новыми промышленными предприятиями.

В связи с тем, что модель советской модернизации была догоняющей, процессы урбанизации приобретали мобилизационный характер, в рамках которого государство не просчитывало неизбежно возникающие экологические риски: форсирование индустриализации представлялось неизмеримо более важным, чем разрушение городской экосистемы. В результате урбанизация (в рамках советской версии социализма) обрела не только свое социальное содержание, но и особый движущий механизм в лице государства, а её поспешность породила не только «уникальность и парадоксальность, но и ущербность» [2, с.105]. Политическая идеология, квинтэссенцией которой было стремление не только догнать, но и перегнать Запад по темпам промышленного производства, не принимала в расчет проблемы, связанные концентрацией на ограниченной территории фабрик и заводов, а также необходимых для их деятельности людских ресурсов.

Характер урбанизации, типичный для советского периода, был обусловлен не только соответствующей политической стратегией, но и исторически сложившейся спецификой развития российского социума, который развивался как общество мобилизационного типа. Его особенность - быстро реагировать на ситуацию угрозы, способность концентрировать все имеющиеся ресурсы для решения наиболее острой проблемы, стремление к быстрому достижению поставленной цели (вне зависимости от цены вопроса), предельно сжатые сроки выполнения намеченного. Инструмент, позволявший реализовывать подобные задачи - примат государства над обществом, сверхцентрализованная система управления и аккумулирование власти в одних руках, мощный карательно-репрессивный аппарат и действенная политическая идеология. По мнению исследователей, специфику функционирования российских политических и экономических институтов определил вполне объективный фактор - природно-климатические условия, которые, в конечном итоге, и обусловили мобилизационный характер развития российского общества.

Советская урбанизация носила половинчатый характер и имела явный перекос в сторону развития промышленности и производственной инфраструктуры, оставаясь чуждой решению проблемы развития культурного 


\section{НАУКА, ОБЩЕСТВО, ТЕХНОЛОГИИ: ПРОБЛЕМЫ И ПЕРСПЕКТИВЫ ВЗАИМОДЕЙСТВИЯ В СОВРЕМЕННОМ МИРЕ}

пространства города и инвестирования в человека. В результате возник дисбаланс между новациями (быстрым ростом городов, увеличением численности их населения) и традиционализмом (аграрной ментальностью и сельским общинным сознанием новых горожан, низким уровнем их жизни, архаично-экстенсивным характером городской деятельности) [2].

Сам процесс градостроительства в СССР осуществлялся в рамках директивной экономики. В ситуации необходимости осуществления массового жилищного строительства и объектов городской инфраструктуры, имевших социальное назначение, на первый план выходил экономический критерий дешевизна, что влекло за собой создание унылой и однообразной городской среды, в которой проходила жизнь советского человека. Несмотря на провозглашенный лозунг - «Все во имя человека, все для блага человека» - политика развития городов была основана на жесткой экономии. Социально-значимые сферы - бытовая, жилищная, культурная финансировались по остаточному принципу.

В советский период возникло понятие «градообразующее предприятие», которое отражало новые реалии: системообразующим элементом города выступало то, или иное промышленное производство. Новый город не возникал естественно, из органичной потребности территории и имеющихся ресурсов (людских и материальных), а был результатом целенаправленных усилий государства, размещающего там, где это было нужно, производительные силы. В отсутствие жестких нормативных документов, регламентирующих природопользование, и действенных инструментов утилизации промышленных отходов, функционирование производств сопровождалось всеми мыслимыми формами загрязнения окружающей среды - атмосферы, водоемов и почвы, а также скоплением промышленных отходов в непосредственной близости от жилых построек. В погоне за наращиванием производственных мощностей и объемов производимой продукции необходимость сохранения биоресурсов, выполнения минимальных экологических требований, совокупность которых в итоге влияла на социальную жизнь, в расчет не принимались.

Поскольку основной функцией у многих советских городов была функция производственная, проблема сохранения водных ресурсов, создания рекреационных и зеленых зон не представлялась значимой. Напротив, имели место характерные для промышленных городов результаты деятельности промышленных предприятий: от токсичных выбросов в атмосферу и загрязнения водоемов - до скопления промышленных отходов вблизи мест 


\section{НАУКА, ОБЩЕСТВО, ТЕХНОЛОГИИ: ПРОБЛЕМЫ И ПЕРСПЕКТИВЫ ВЗАИМОДЕЙСТВИЯ В СОВРЕМЕННОМ МИРЕ}

проживания городского населения. В связи с тем, что основной целью выступало выполнение плана по индустриализации страны, а не поддержание стабильного состояния экосистемы, «зеленый свет» получало развитие промышленных зон, в которых нуждалось народное хозяйство и военнопромышленный комплекс страны. В результате, основа комплекса экологических проблем, с которыми сталкивается современная Россия, во многом была заложена советской урбанизацией.

Обращаясь к исследованию природоохранной деятельности в советский период, ученые утверждают, что на первом этапе (1917-1960 гг.) «политика советского государства в сфере взаимодействия общества и природы носила жесткий эксплуатирующий характер, оправданием которому считалось стремление в короткие сроки создать в стране развитое социалистическое общество» [3].

Проблема рационального природопользования и проведения природоохранных мероприятий становится актуальной в тот момент, когда предельно отчетливо обозначились угрозы экологического характера. Рубежными стали 70-е гг. XX века. В постановлениях органов власти различного уровня начинают звучать призывы, адресованные, прежде всего, к научному сообществу. Их суть сводилась к необходимости выработки научно обоснованных принципов и методов регулирования отношений человека и природы, созданию природосберегающих и ресурсосберегающих научных технологий.

Несмотря на определенные позитивные изменения, связанные с началом осознания имеющихся экологических проблем, в 70-е гг. продолжала сохраняться дискретность между декларациями и практическими действиями. Природоохранная политика так и не приобрела последовательного характера, а приоритет в вопросах развития продолжал оставаться за промышленными предприятиями. Закономерным следствием стало дальнейшее обострение кризисных тенденций в экологии.

В постсоветский период - с 90-х гг. ХX века - начали происходить существенные социально-экономические изменения, которые во многом были обусловлены предшествующим этапом развития и отразились на урбанизационных процессах. Основной проблемой стал промышленный спад, имевший тяжелые последствия не только для экономики страны, но и для социальной сферы [4]. По мнению исследователей он сказался «на микрогеографии городов и характере использования территории пригородных 


\section{НАУКА, ОБЩЕСТВО, ТЕХНОЛОГИИ: ПРОБЛЕМЫ И ПЕРСПЕКТИВЫ ВЗАИМОДЕЙСТВИЯ В СОВРЕМЕННОМ МИРЕ}

3он» [5]. Среди новых рисков, негативно влияющих на экологию городов в постсоветский период, принято выделять деурбанизацию и мегаполизацию.

Поскольку процесс деурбанизации многоаспектен, современные исследователи рассматривают его с разных точек зрения. Одни усматривают его сущность в социальной деградации городской среды, полагая, что деурбанизация - это контртенденция урбанизации [6]. Другие видят в деурбанизации социальное явление, обусловленное миграционными и экономическими факторами [7]. Третьи рассматривают деурбанизацию через призму изменений в культуре (от размывания самого феномена городской культуры до попыток духовной эмансипации индивида от ценностных установок города)[8]. Вариативность трактовок сущности деурбанизации свидетельствует о сложности данного явления, но неизменно указывает на трансформацию самой городской среды и различных аспектов жизни людей, связанный с этой средой.

Что касается постсоветской деурбанизации, то она оказалась связана, в первую очередь, с деиндустриализацией страны. Как было отмечено ранее, в советский период имела место ускоренная индустриализация, получали развитие новые производственные структуры, возникали, по сути дела, моногорода, в основе которых находилось то или иное градообразующее предприятие. Советские моногорода - места притяжения различных ресурсов финансовых, материальных и трудовых [9].

Закономерным следствием банкротства градообразующих промышленных предприятий стали тяжелые экономические и социальные последствия. Снижение доходов населения, падение темпов рождаемости и увеличение смертности, оживление внутренней миграции, связанной с оттоком трудоспособного населения в относительно благоприятные экономические зоны. В отсутствие инвестиций моногорода начали быстро деградировать, превращаясь в депрессивные территории, которые переставали отвечать градостроительным, социально-экономическим и экологическим требованиям[10]. В результате депрессивные города постепенно утрачивали свою основную промышленно-производственную функцию и ухудшали экологическую ситуацию.

На деятельности промышленных предприятий, которые продолжали работать в новых условиях, негативно сказались общие кризисные тенденции: отсутствие финансирования и изношенность основных фондов. Невозможность, а подчас и нежелание руководства предприятий осуществлять 


\section{НАУКА, ОБЩЕСТВО, ТЕХНОЛОГИИ: ПРОБЛЕМЫ И ПЕРСПЕКТИВЫ ВЗАИМОДЕЙСТВИЯ В СОВРЕМЕННОМ МИРЕ}

природоохранных меры, вело к дальнейшему загрязнению окружающей среды. Серьезно сказывался на экологической ситуации и профиль производственной деятельности моногородов. Если промышленные предприятия загрязняли прежде всего атмосферу, то агропромышленная деятельность и разработка месторождений полезных ископаемых приводили не только к загрязнению почв и водоемов, повышению естественного уровня радиационного фона, но и к необратимым изменениями природных ландшафтов. Отдельной и неразрешимой проблемой оставалась утилизация промышленных и бытовых отходов. Возникшие проблемы не могло решить даже закрытие подобных предприятий, поскольку нанесенный ими экологический урон требовал масштабных мероприятий и значительного финансирования.

Экологическая деградация городской территории, ставшая следствием процесса деурбанизации, многолика, но чаще всего проявляет себя в заброшенных промышленных зонах и несанкционированных свалках. Социально-экономическое отставание бывших советских моногородов не в последнюю очередь обусловлено их экологическим неблагополучием: подобные города мало привлекательны для инвесторов. В современных условиях экологические аспекты развития городов перестают восприниматься как что-то избыточное, напротив, именно своевременное решение экологических проблем и наличие внятной программы экологического развития моногородов способно обеспечить их устойчивость.

Зоны экологического неблагополучия являются печальной реальностью большинства современных российских моногородов. Они несут на себе печать предшествующего тренда развития, связанного с высоким уровнем индустриализации, преобладанием природоёмких отраслей и использованием устаревших технологий. Так бывшие «шахтерские города», возникшие вокруг шахт, ведущих добычу полезных ископаемых, прежде всего каменного угля, с течением времени превратились в зоны экологического неблагополучия. Нерентабельные шахты не были законсервированы или ликвидированы с учетом необходимых экологических требований. Результатом стал выход на поверхностность шахтных вод, подтопление территорий, загрязнение воды в колодцах и скважинах, выделение газа метан, опасного для жизни и многое другое [11]. Помимо негативного воздействия на почвенную и водную среды серьезно пострадала атмосфера, подвергшаяся загрязнению соединениями тяжелых металлов (цинка, свинца, меди, хрома) [12]. 
Вышесказанное позволяет прийти к следующему выводу: угрозы экологической безопасности современного городского пространства порождены советской урбанизацией и постсоветской деурбанизацией. Комплекс проблем вызван технологическими (устаревшие энергозатратные технологии), финансовыми (отсутствие инвестиций для диверсификации производств и восстановления экосистемы) и социальными (демографический кризис) причинами.

\section{Список литературы}

1. Сенявский А. С. Урбанизация России в XX веке: роль в историческом процессе. М.: Наука, 2003. 288 с.

2. Пивоваров Ю. Л. Урбанизация в России в XX веке: представление и реальность // Общественные науки и современность. 2001. № 6. С. 105. С. 101113.

3. Макеева Е. Д. Природоохранная политика СССР в 1960-1980-х гг.: успехи, провалы и противоречия // История и археология: материалы IV Междунар. науч. конф. (г. Санкт-Петербург, июль 2017 г.). СПб.: Свое издательство, 2017. [Электронный ресурс] URL: https: // moluch.ru/conf/hist/archive/243/12646/ (дата обращения: 26.06.2021).

4. Meisner T. N., Kovalev N.A., Lyashenko N.V., LepikhovaV.A. The Ecohumanization concept of a modern city in the transition of society from industrialism to humanism // EurAsian Journal of BioScences. 2019. № 13 (2). P. 1659-1665.

5. Балдано М. Н. Советская модель урбанизации // Вестник Бурятского госуниверситета. 2009. №7. С.55. С. 53-56.

6. Бон Томас М. «Социалистический город» или «европейский город»: урбанизация и рурализация в Восточной Европе // Российская история. 2009. № 1. С. $65-76$.

7. Комков Д. Е., Киричек П. Н. Регионы в зоне демографического риска: минус-тенденции миграции и урбанизации // Регионология. 2017. № 1(98). C. $139-148$.

8. Киреева О.В. Урбанизация и дезурбанизация в истории русской культуры // Парадигма: философско-культурологический альманах. 2020. № 32. C.80-95. 
9. Дмитриева Е. О., Мост Е. С. Экологические проблемы устойчивого развития моногорода Чапаевск и пути их решения на современном этапе // Вестник Евразийской науки. 2018. №6. С. 157-165.

10. Родяшина К. Е. Депрессивные территории в структуре современного города: понятия, характеристики, классификация // Вестник БГТУ им. В. Г. Шухова. 2017. № 8. С.106-114.

11. Жигулин А. А., Канивец Е. П., Руденко Л. В. Экологические проблемы в развитии шахтерских городов Донбасса и пути их решения [Электронный pecypc] URL: https:// ea.donntu.org: 8080/bitstream/123456789/18329/1 (дата обращения: 12.04.2021).

12. Приваленко В. В., Кузина 3. Р., Коломенский Г. Ю., Гипич Л. В. Экологические проблемы Восточного Донбасса // Известия вузов. СевероКавказский регион. Естественные науки. 2004. №7. С.36-49.

(C) Т.Н. Майснер, 2022 